
Journal

\title{
Risk assessment and source identification of coastal groundwater nitrate in northern China using dual nitrate isotopes combined with Bayesian mixing model
}

Xiaohu Wen, Qi Feng, Jian Lu, Jun Wu, Min Wu \& Xiaoyan Guo

To cite this article: Xiaohu Wen, Qi Feng, Jian Lu, Jun Wu, Min Wu \& Xiaoyan Guo (2018) Risk assessment and source identification of coastal groundwater nitrate in northern China using dual nitrate isotopes combined with Bayesian mixing model, Human and Ecological Risk Assessment: An International Journal, 24:4, 1043-1057, DOI: 10.1080/10807039.2017.1405722

To link to this article: https://doi.org/10.1080/10807039.2017.1405722

\section{舟 Published online: 21 Dec 2017.}

Submit your article to this journal $[\pi$

LII Article views: 12

Q View related articles $\square$

View Crossmark data ¿ 


\title{
Risk assessment and source identification of coastal groundwater nitrate in northern China using dual nitrate isotopes combined with Bayesian mixing model
}

\author{
Xiaohu Wen ${ }^{a, b}$, Qi Feng ${ }^{a, b}$, Jian $L^{c}{ }^{c}$, Jun $W^{d}{ }^{d}$, Min Wu ${ }^{a, b}$, and Xiaoyan Guo ${ }^{a, b}$ \\ ${ }^{a}$ Key Laboratory of Ecohydrology of Inland River Basin, Chinese Academy of Sciences, Lanzhou, Gansu, People's \\ Republic of China; ${ }^{b}$ Northwest Institute of Eco-Environment and Resources, Chinese Academy of Sciences, \\ Lanzhou, Gansu, People's Republic of China; 'Key Laboratory of Coastal Environmental Processes and Ecological \\ Remediation, Yantai Institute of Coastal Zone Research, Chinese Academy of Sciences, Yantai, Shandong, \\ People's Republic of China; 'Q Qinghai Institute of Salt Lakes, Chinese Academy of Sciences, Xining, Qinghai, \\ People's Republic of China
}

\begin{abstract}
Due to the intensive and complicated human activities, the identification of nitrate pollution source of coastal aquifer is usually a challenge. This study firstly adopted stable isotope technique and stable isotope analysis in $R$ (SIAR) model to identify the nitrate sources and contribution proportions of different sources in typical coastal groundwater of northern China. The results showed that about $91.5 \%$ of the groundwater samples illustrated significantly high nitrate concentrations exceeding the maximum WHO drinking water standard $(50 \mathrm{mg} / \mathrm{l})$, reflecting the high risk of groundwater nitrate pollution in the coastal area. A total of 57 sampling sites were classified into three groups according to hierarchical cluster analysis (HCA). The $\delta^{15} \mathrm{~N}_{-} \mathrm{NO}_{3}{ }^{-}$and $\delta^{18} \mathrm{O}$ $\mathrm{NO}_{3}{ }^{-}$values of groundwater samples from Group $\mathrm{C}$ (including nine samples) were much higher than those from Group A (including 40 samples) and Group B (including 8 samples). SIAR results showed that $\mathrm{NH}_{4}{ }^{+}$fertilizer was the dominant nitrate source for groundwater samples of Groups $A$ and B while manure and sewage (M\&S) served as dominant source for Group C. This study provided essential information on the high risk and pollution sources of coastal groundwater nitrate of northern China.
\end{abstract}

\section{ARTICLE HISTORY}

Received 22 September 2017 Revised manuscript accepted 13 November 2017

\section{KEYWORDS}

groundwater nitrate pollution; source identification; dual nitrate isotopes; hierarchical cluster analysis; stable isotope analysis in $R$ model

\section{Introduction}

Known as an important earth's critical zone, the coastal zone is dramatically influenced by the anthropogenic activities. Therefore, groundwater in this area has shown various problems such as seawater intrusion (De Filippis et al. 2016), land subsidence due to overexploitation of the groundwater ( $\mathrm{Hu}$ et al. 2004), and groundwater pollution ( $\mathrm{Re}$ et al. 2013). Groundwater nitrate pollution has remarkable effects on coastal ecosystem and human health, which thus becomes an important issue for this area. Nitrate pollution of

CONTACT Jian Lu $\otimes$ jlu@yic.ac.cn E Key Laboratory of Coastal Environmental Processes and Ecological Remediation, Yantai Institute of Coastal Zone Research, Chinese Academy of Sciences, Yantai, Shandong, 264003, People's Republic of China. Color versions of one or more of the figures in the article can be found online at www.tandfonline.com/bher. 
groundwater is a worldwide issue attracting extensive attention by the public (Gu et al. 2013; Hosono et al. 2013; Menció et al. 2016). Intensive anthropogenic activities have caused large amount of nitrogen matters that are discharged into the groundwater. Therefore, nitrate concentrations of the groundwater continuously increase to seriously disturb fate and transport of nitrate in the groundwater and extensively affect the human health and ecological stability ( $\mathrm{Gu}$ et al. 2013; Miller et al. 2016; Musgrove et al. 2016). Identification of the groundwater nitrate sources has become an important issue for preventing and controlling groundwater nitrate pollution (Hosono et al. 2013; Matiatos 2016). However, it is usually difficult to identify groundwater nitrate pollution because of multiple factors including uncertainty of groundwater nitrate sources, complexity of nitrate transformation, and retardant effects of groundwater nitrate. Therefore, identification of nitrate sources in groundwater will not only lay the scientific basis on evaluating groundwater resources but also have important sense in theory and practice for prevention and control of groundwater pollution.

There are diverse groundwater nitrate sources such as fertilizer and manure, industrial and domestic sewage, atmospheric $\mathrm{N}$ deposition, and soil organic $\mathrm{N}$ (Kendall 1998). Various nitrate sources and complex physic-chemical reactions in nitrogen cycle have caused remarkable shortcoming using individual approach for source identification (Hosono et al. 2013). Stable isotope technique has been gradually employed to identify the nitrate sources along with the development of this technique (Kaown et al. 2009; Matiatos 2016). Generally, $\delta^{15} \mathrm{~N}^{-\mathrm{NO}_{3}}{ }^{-}$values range from $-6 \%$ to $+6 \%$ for fertilizers, from $-13 \%$ o to $+13 \%$ for atmospheric $\mathrm{N}$ deposition, from $+5 \%$ o to $+25 \%$ o for manure, from $+4 \%$ o to $+19 \%$ o for sewage, and from $0 \%$ to $+8 \%$ or for soil $\mathrm{N}$ while $\delta^{18} \mathrm{O}-\mathrm{NO}_{3}{ }^{-}$values range from $-10 \%$ o to $+10 \%$ o for nitrate derived from nitrification, from $+25 \%$ to $+75 \%$ for atmospheric $\mathrm{N}$ deposition, and from $+17 \%$ o to $+25 \%$ for fertilizers (Bateman and Kelly 2007; Finlay et al. 2007; Hales et al. 2007; Lee et al. 2008; Singleton et al. 2007; Xue et al. 2009). Individual isotope method shows limitations such as overlapping isotope value range and variance in isotope values of target groundwater and source sites due to isotope fractionation. Therefore, individual isotope approach cannot accurately identify the nitrate source of groundwater (Hosono et al. 2013). Quantitatively evaluating the contribution proportions of the different nitrate sources is important for prevention and control of groundwater nitrate pollution. Based on stable isotope technique, many models for identifying source contribution have been established (Moore and Semmens 2008; Parnell and Jackson 2008; Parnell et al. 2010; Matiatos 2016; Grimmeisen et al. 2017). SIAR (Stable Isotope Analysis In $R$ ) is a Bayesian mixing model based on Direchlet distribution (Jackson et al. 2009; Parnell and Jackson 2008), showing good ability of solving limits of mass-balance mixing models. SIAR model has been applied to evaluate the contribution of different nitrate sources (Yue et al. 2015a; Xue et al. 2012; Matiatos 2016), exhibiting good application potential.

Freshwater resources in coastal zones are limited while demands are high, resulting in strict water resource management and protection of coastal freshwater aquifers. In the face of growing water scarcity, groundwater is an important water supply in the coastal zone. Many attempts have been devoted to protecting the groundwater in coastal zone. Due to the rapid increase in population and remarkable economic development in the coastal zone in China, water demands have become greater and groundwater has been over-abstracted. Due to the intensive and complicated human activities in coastal area, the identification of nitrate source of coastal aquifer is usually a challenge. This study adopted stable isotope technique and SIAR model to identify the nitrate sources and contribution proportions of 
different source in typical coastal groundwater in northern China. It aims at providing essential information on the coastal groundwater protection and pollution control in northern China.

\section{Methods and materials}

\section{Study area}

The study area is a typical coastal zone located in the eastern Laizhou Bay, northern China, bordering on Bohai Sea in the north (Figure 1). Laizhou Bay coastal area was affected by extremely intensive anthropogenic activities in China. Groundwater in this area has been over-abstracted for the last few decades. Therefore, seawater intrusion in coastal aquifer throughout this area has become the most serious in China (Yin 1992). The annual exploitation of groundwater in the eastern Laizhou Bay was $1.54 \times 10^{8} \mathrm{~m}^{3}$ in 2003 ( $\mathrm{Li} 2005$ ), thus significantly decreasing groundwater levels. It is under continental monsoon climate with an average annual temperature of $12.4^{\circ} \mathrm{C}$. The average annual precipitation is $640.3 \mathrm{~mm}$, mainly (about 72.4\%) distributing from June to September. The average annual

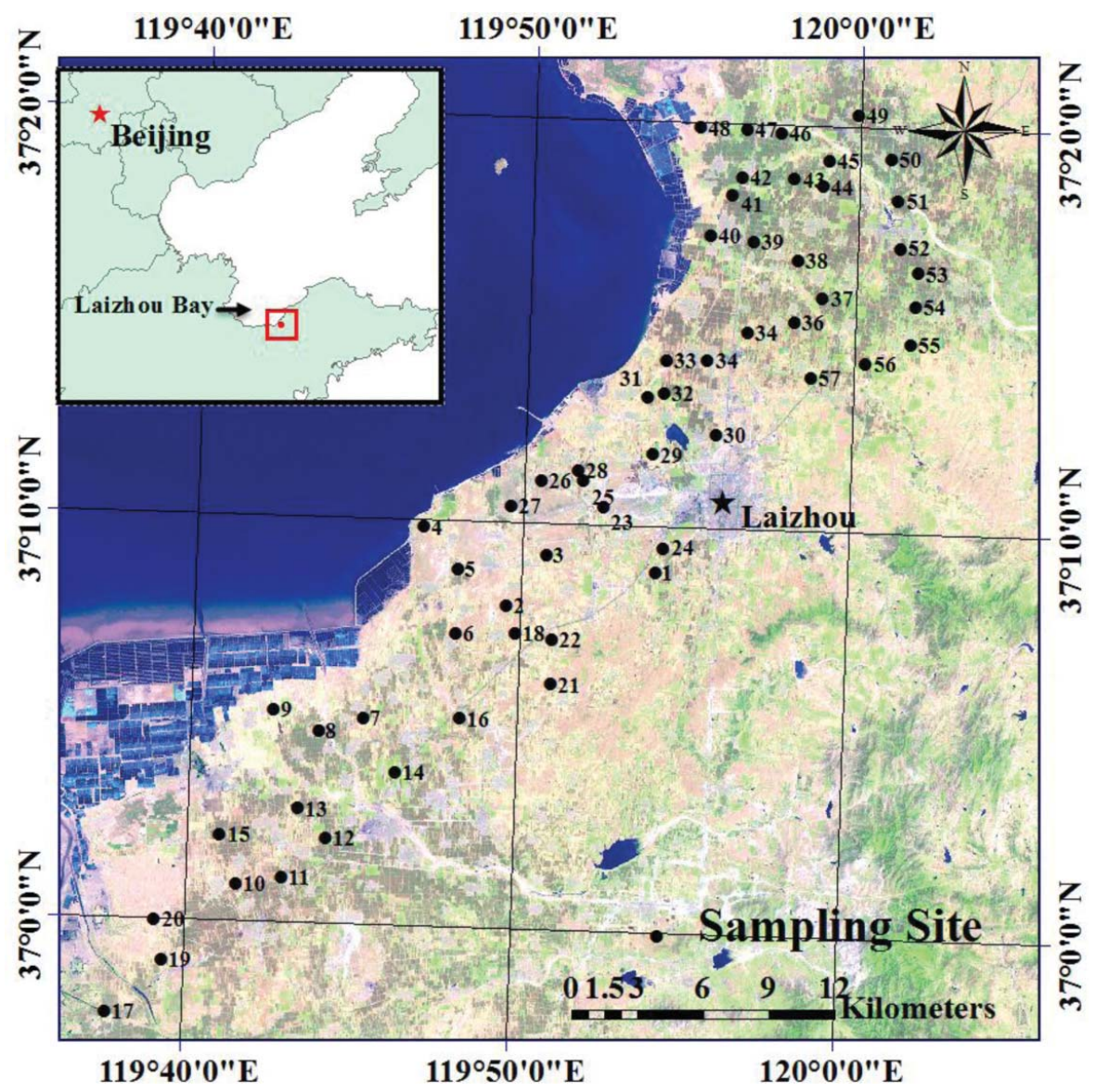

Figure 1. Study area and sampling sites. 
potential evaporation is $2,118.7 \mathrm{~mm}$ (Fu et al. 1994). The study area shows five types of landforms (i.e. marine deposits plain, alluvial plain, pluvial plain, and bedrock hills) spreading from coast to inland, being made up of sandbar, lagoon, and bedrock. With the width of 510 and $2-3 \mathrm{~km}$ in some parts, the plains distribute in the shape of belt in east-north direction. The study area possesses two types of water-bearing bodies including Quaternary loose beds and bedrock-fissured aquifer. The Quaternary water-bearing beds are made up of fluvial and pluvial sediments, sand layers, and talus strata, with the deposit thickness of 10$100 \mathrm{~m}$ in the west and 15-25 $\mathrm{m}$ in the east. There are 2-3 aquifers made up of different litho facies such as gravel sand, coarse sand, medium-granular sand, and small-granular sand, and then transiting to the sediments of marine phase or lagoon phase. Upper aquifers are in close hydraulic connection with lower aquifers due to a large amount of borehole withdrawal and "deposit windows." The detailed information on the hydrology of the study area refers to Wen et al. (2012).

\section{Sampling and chemical analysis}

Field sampling and investigation were carried out in June 2013 to evaluate groundwater nitrate pollution in the study area. Fifty-seven groundwater samples were collected from long-term groundwater observation wells and drinking wells with depths of 5-40 m (Figure 1). Water temperature (T), pH, dissolved oxygen (DO), and electrical conductivity (EC) of the groundwater samples were measured in situ using a portable water quality analyzer (HQd30, Hach, USA). Water samples were filtered through a $0.45-\mu \mathrm{m}$ cellulose-acetate filter and stored at $4^{\circ} \mathrm{C}$ until chemical and isotope analysis. The concentrations of $\mathrm{NO}_{3}{ }^{-}$, $\mathrm{Cl}^{-}, \mathrm{SO}_{4}{ }^{2-}, \mathrm{Na}^{+}, \mathrm{K}^{+}, \mathrm{Mg}^{2+}$, and $\mathrm{Ca}^{2+}$ were analyzed using ion chromatography (ICS3000, Dionex, USA). The concentrations of $\mathrm{HCO}_{3}{ }^{-}$were determined using titration.

The stable isotope $\delta^{18} \mathrm{O}-\mathrm{H}_{2} \mathrm{O}$ compositions of groundwater samples were analyzed using an isotope ratio mass spectrometer (MAT-253, Thermo Scientific, USA). The $\delta^{15} \mathrm{~N}$ $\mathrm{NO}_{3}{ }^{-}$and $\delta{ }^{18} \mathrm{O}-\mathrm{NO}_{3}{ }^{-}$compositions were analyzed using the denitrifier method at the Facility for Isotope Ratio Mass Spectrometry, University of California, Riverside. All stable isotope results are expressed in the delta $(\delta)$ units of per mil (\%) relative to a suitable standard. Vienna Standard Mean Ocean Water (VSMOW) standard was used for $\delta^{18} \mathrm{O}-\mathrm{H}_{2} \mathrm{O}$ and $\delta^{18} \mathrm{O}-\mathrm{NO}_{3}{ }^{-}$while atmospheric nitrogen gas $\left(\mathrm{N}_{2}\right)$ was used for $\delta^{15} \mathrm{~N}-\mathrm{NO}_{3}{ }^{-}$. More detailed information on the determination procedure and main principles for $\delta^{15} \mathrm{~N}^{-\mathrm{NO}_{3}}{ }^{-}$and $\delta^{18} \mathrm{O}$ $\mathrm{NO}_{3}{ }^{-}$refers to Yang et al. (2013).

\section{Data analysis}

Since several chemical and isotopic sub-datasets did not follow a normal distribution, nonparametric tests (Mann-Whitney and Kruskal-Wallis) were used to evaluate these datasets by comparing the average values of two independent samples (subgroups). Data selection obeys the null hypothesis stating that two or more samples taken from a single population would have no consistent differences between two or more ranking sets. When the calculated $p$-value is less than 0.05 , two groups are significantly different. Hierarchical cluster analysis (HCA) was adopted to classify Ward's linkage rule which iteratively linked nearby data through a similarity matrix. ANOVA was performed to evaluate the distance between different clusters. The squared Euclidian distance was selected for the similarity measurement. 
$\delta^{15} \mathrm{~N}-\mathrm{NO}_{3}{ }^{-}$and $\delta^{18} \mathrm{O}_{-\mathrm{NO}_{3}}{ }^{-}$values were standardized based on $\mathrm{z}$-scores. All statistical calculations were performed using SPSS 20.0.

\section{Estimation of nitrate source contributions (SIAR)}

To quantify the contributions of the $\mathrm{NO}_{3}{ }^{-}$sources to groundwater, a Bayesian mixing model SIAR (Stable Isotope Analysis In R) was used (Parnell and Jackson 2008; Parnell et al. 2010). By defining a set of $N$ measurements on $J$ isotopes with contributions of $K$ sources, the SIAR model can be expressed as follows (Parnell et al. 2010):

$$
\begin{aligned}
X_{i j} & =\sum_{k=1}^{k} p_{k}\left(S_{j k}+c_{j k}\right)+\varepsilon_{i j} \\
S_{j k} & \sim N\left(\mu_{j k}, \omega_{j k}^{2}\right) \\
c_{j k} & \sim N\left(\lambda_{j k}, \tau_{j k}^{2}\right) \\
\varepsilon_{i j} & \sim N\left(0, \sigma_{j}^{2}\right)
\end{aligned}
$$

where $X_{i j}$ is the observed isotope value $j$ of mixture $i$, in which $i=1,23, \ldots, I$ and $j=1,2,3$, $\ldots, J ; S_{j k}$ refers to the source value $k$ on isotope $j(k=1,23, \ldots, K)$ that is normally distributed with mean $\mu_{j k}$ and variance $\omega_{j k} ; p_{k}$ is the proportion of source $k$, which needs to be estimated by the SIAR model; $c_{j k}$ is the isotope fractionation factor for isotope $j$ on source $k$, being normally distributed with mean value $\lambda_{j k}$ and standard deviation $\tau_{j k}$; and $\varepsilon_{i j}$ is the residual error representing the additional unquantified variation between individual mixtures and is normally distributed with mean 0 and standard deviation $\sigma_{j}$. Detailed information on SIAR model refers to Parnel et al. (2010).

Due to the lack of the information on the $\delta^{15} \mathrm{~N}_{-\mathrm{NO}_{3}}{ }^{-}$and $\delta^{18} \mathrm{O}-\mathrm{NO}_{3}{ }^{-}$isotope characteristic values for the potential nitrate sources in the study area, the mean value and standard deviation of each source nitrate isotope signature were cited from literatures (Kendall et al. 2007; Chae et al. 2009; Kaown et al. 2009; Xue et al. 2009; Urresti-Estala et al. 2015; Yue et al. 2015a; Yue et al. 2015b). The isotope fractionation factor $c_{j k}$ for all sources was set as zero because no significant signs of nitrogen transformation occurred in the groundwater during the sampling periods.

\section{Results and discussion}

\section{Risk assessment and isotope compositions of coastal groundwater nitrate}

The statistical summary of water quality parameters was shown in Table 1 . The nitrate concentrations ranged from 9.35 to $660.88 \mathrm{mg} / \mathrm{l}$, with an average value of $190.65 \mathrm{mg} / \mathrm{l}$. The nitrate concentration in groundwater is generally less than $10 \mathrm{mg} / \mathrm{l}$ under the natural condition (ECETOC 1988). Except one sample, the remaining 56 groundwater samples exhibited high nitrate concentrations (exceeding $10 \mathrm{mg} / \mathrm{l}$ ), indicating that anthropogenic contamination has dramatically increased nitrate concentrations in the groundwater. In particular, about $91.5 \%$ of the groundwater samples showed remarkably high nitrate concentrations which exceeded the recommended maximum allowable value for nitrate in drinking water according to the WHO $(50 \mathrm{mg} / \mathrm{l})$, indicating the high risk of groundwater nitrate pollution 
Table 1. Statistical summary of groundwater parameters.

\begin{tabular}{|c|c|c|c|c|c|}
\hline & Minimum & Maximum & Mean & Standard deviation & Skewness \\
\hline $\mathrm{pH}$ & 7.00 & 7.68 & 7.38 & 0.15 & -0.13 \\
\hline $\mathrm{EC}(\mu \mathrm{S} / \mathrm{cm})$ & 509.00 & 3650.00 & 1416.96 & 513.92 & 1.50 \\
\hline $\mathrm{DO}(\mathrm{mg} / \mathrm{l})$ & 3.42 & 10.22 & 7.21 & 1.49 & -0.28 \\
\hline $\mathrm{Na}^{+}(\mathrm{mg} / \mathrm{l})$ & 22.11 & 532.87 & 80.39 & 75.04 & 4.31 \\
\hline $\mathrm{K}^{+}(\mathrm{mg} / \mathrm{l})$ & 0.11 & 18.56 & 1.96 & 2.67 & 4.73 \\
\hline $\mathrm{Mg}^{2+}(\mathrm{mg} / \mathrm{l})$ & 10.42 & 77.20 & 30.89 & 14.48 & 1.21 \\
\hline $\mathrm{Ca}^{2+}(\mathrm{mg} / \mathrm{l})$ & 37.84 & 383.53 & 192.11 & 73.65 & 0.25 \\
\hline $\mathrm{Cl}^{-}(\mathrm{mg} / \mathrm{l})$ & 34.45 & 1319.82 & 224.05 & 190.35 & 3.66 \\
\hline $\mathrm{NO}_{3}{ }^{-}(\mathrm{mg} / \mathrm{l})$ & 9.35 & 660.88 & 196.87 & 131.54 & 1.36 \\
\hline $\mathrm{SO}_{4}^{2-}(\mathrm{mg} / \mathrm{l})$ & 35.66 & 271.40 & 108.77 & 56.29 & 0.95 \\
\hline $\mathrm{HCO}_{3}^{-}(\mathrm{mg} / \mathrm{l})$ & 124.56 & 500.96 & 282.74 & 75.65 & 0.49 \\
\hline TDS (mg/l) & 258.09 & 2795.71 & 979.82 & 422.96 & 1.48 \\
\hline$\delta^{15} \mathrm{~N}-\mathrm{NO}_{3}{ }^{-}(\%)$ & 3.06 & 18.57 & 7.52 & 2.77 & 1.34 \\
\hline$\delta^{18} \mathrm{O}-\mathrm{NO}_{3}-(\%)$ & 0.07 & 8.01 & 3.43 & 1.71 & 0.58 \\
\hline$\delta^{18} \mathrm{O}-\mathrm{H}_{2} \mathrm{O}(\% 0)$ & -8.35 & -4.63 & -7.19 & 0.73 & 1.19 \\
\hline
\end{tabular}

in the coastal area. Nitrate concentrations reached $600 \mathrm{mg} / \mathrm{l}$ at some sampling sites, which reflected the extremely high risk of groundwater nitrate pollution in the coastal area.

Most of groundwater quality parameters varied in very wide ranges and high standard deviations (Table 1). The $\mathrm{pH}$ values ranged from 7.00 to 7.88 with an average of 7.40 , indicating a slight tendency toward a basic composition. DO varied from 3.42 to $11.49 \mathrm{mg} / \mathrm{l}$ with an average of $7.29 \mathrm{mg} / \mathrm{l}$ to illustrate oxic conditions. Groundwater samples showed highly dispersed EC values, ranging from 490 to $3650 \mu \mathrm{S} / \mathrm{cm}$. The $\mathrm{Cl}^{-}$concentrations also had a wide range between 42.68 and $1319.82 \mathrm{mg} / \mathrm{l}$ with an average of $218.25 \mathrm{mg} / \mathrm{l}$. Concentrations of $\mathrm{Ca}^{2+}$, $\mathrm{Mg}^{2+}, \mathrm{K}^{+}, \mathrm{HCO}_{3}{ }^{-}$, and $\mathrm{SO}_{4}{ }^{2-}$ also showed remarkable variations (Table 1), indicating that chemical composition was affected by diverse hydro-chemical processes (Park et al. 2005).

The $\delta^{15} \mathrm{~N}^{-\mathrm{NO}_{3}}{ }^{-}$values in the groundwater ranged from $+3.06 \%$ o to $+18.57 \%$, with an average value of $+7.52 \%$. The $\delta^{18} \mathrm{O}-\mathrm{NO}_{3}{ }^{-}$values in the groundwater varied between $+0.07 \%$ o to $+8.01 \%$, with a mean value of $+3.44 \%$. The wide distributions of $\delta^{15} \mathrm{~N}^{-\mathrm{NO}_{3}}{ }^{-}$ and $\delta^{18} \mathrm{O}-\mathrm{NO}_{3}{ }^{-}$indicated that high nitrate concentrations in groundwater mainly originated from multiple nitrate sources (Xue et al. 2009). The $\delta^{18} \mathrm{O}$ compositions of the groundwater samples ranged from -8.35 to $-4.63 \%$ with an average of $-7.19 \%$.

\section{Distribution of water quality classification based on HCA}

A total of 57 sampling sites were classified into three groups according to HCA (Figures 2 and 3). Furthermore, Kruskal-Wallis test results showed that the differences between each cluster were all significant at the 95\% level $(p<0.05)$. As illustrated in Figure 2 , the $\delta^{15} \mathrm{~N}$ $\mathrm{NO}_{3}{ }^{-}$and $\delta^{18} \mathrm{O}-\mathrm{NO}_{3}{ }^{-}$values of groundwater samples from Group $\mathrm{C}$ were much higher than those from Groups A and B. Group B showed the lowest values of $\delta^{15} \mathrm{~N}^{-\mathrm{NO}_{3}}{ }^{-}$and $\delta^{18} \mathrm{O}-\mathrm{NO}_{3}{ }^{-}$.

Potential nitrate sources in groundwater include soil organic nitrogen, synthetic fertilizers, atmospheric nitrogen deposition, manure, and sewage waste (Kendall 1998). A classical dual isotope approach $\left(\delta^{15} \mathrm{~N}_{-} \mathrm{NO}_{3}{ }^{-}\right.$versus $\left.\delta^{18} \mathrm{O}-\mathrm{NO}_{3}{ }^{-}\right)$was applied to identify the predominant sources of $\mathrm{NO}_{3}{ }^{-}$in the groundwater samples (Figure 4). Due to the absence of nitrate isotope values for potential nitrate sources in the study area, the $\delta^{15} \mathrm{~N}_{-} \mathrm{NO}_{3}{ }^{-}$and $\delta^{18} \mathrm{O}-\mathrm{NO}_{3}{ }^{-}$isotopic composition results were compared to those obtained by Kendall et al. 

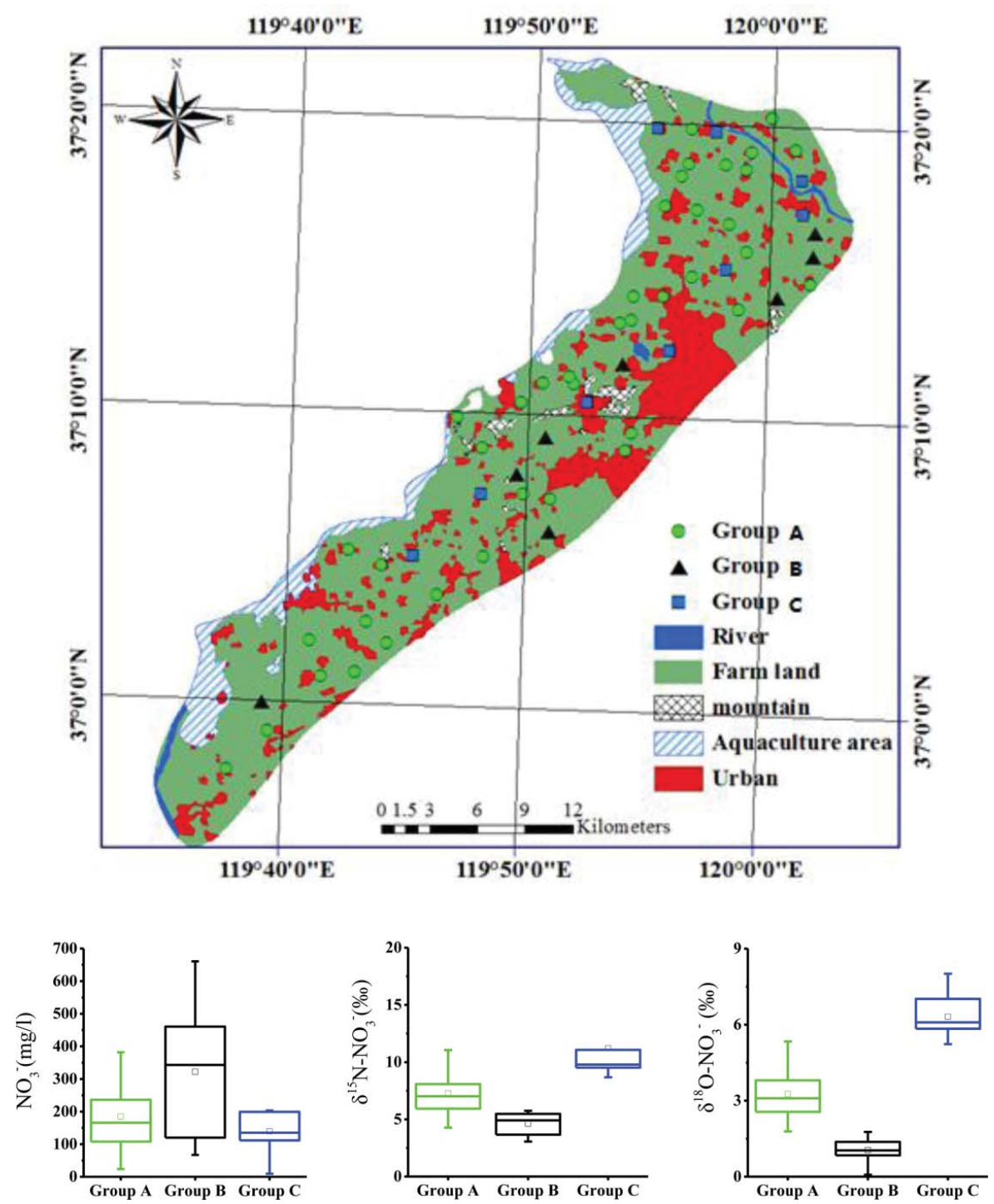

Figure 2. Distribution of water quality classification using HCA.

(2007) and Xue et al. (2009). Figure 4 illustrated that the isotopic signatures of the groundwater samples spread over the range of soil $\mathrm{N}, \mathrm{NH}_{4}{ }^{+}$fertilizer \& soil $\mathrm{N}$, soil $\mathrm{N} \&$ manure and sewage (M\&S).

Nitrate concentrations of Group A ranged from 23.85 to $484.76 \mathrm{mg} / \mathrm{l}$ with an average of $184.75 \mathrm{mg} / \mathrm{l}$. The $\delta^{15} \mathrm{~N}_{-} \mathrm{NO}_{3}{ }^{-}$and $\delta^{18} \mathrm{O}-\mathrm{NO}_{3}{ }^{-}$values of groundwater samples which were classified into Group A ranged from +4.28 to $+11.82 \%$ and from +1.76 to $+5.31 \%$, respectively (Figure 2). It was observed visually that the samples did not fall into the ranges for a specific source (Figure 4), illustrating that these groundwater samples most likely possessed multiple nitrate source inputs. The isotopic signatures of nitrate were close to a mixture of nitrate in soil N, $\mathrm{NH}_{4}{ }^{+}$fertilizer, and M\&S (Figure 4), suggesting that nitrate was influenced by these nitrate sources. This is consistent with the land use pattern in the study area. The 


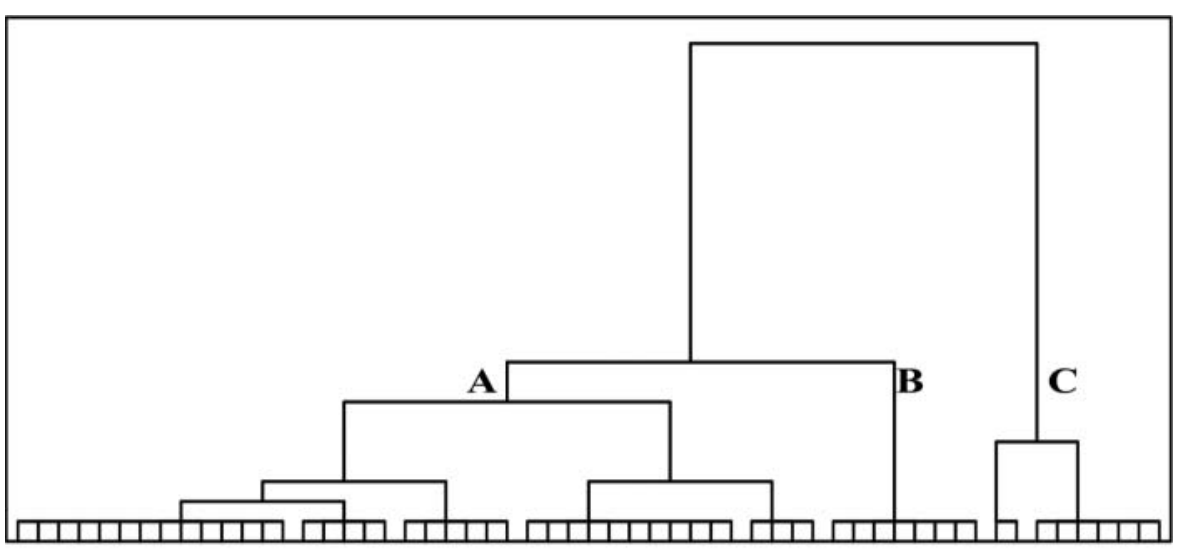

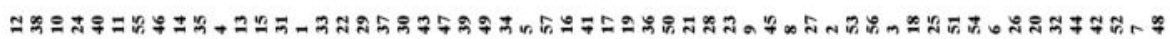

Figure 3. Water quality classification of different sampling sites using HCA.

most of Group A sampling sites are located in the agricultural areas. However, these sampling sites are not far from the residential areas where crops receive synthetic $\mathrm{NH}_{4}{ }^{+}$fertilizer, manure, and sewage from the residential areas. Additionally, several sampling sites lay near the coastal aquaculture area where the aquaculture sewage was discharged. Therefore, groundwater in these sites is affected by multiple nitrate sources.

A total of eight samples were clustered into Group B with $\delta^{15}{\mathrm{~N}-\mathrm{NO}_{3}}^{-}$values between $+3.06 \%$ and $+5.74 \%$ and $\delta^{18} \mathrm{O}-\mathrm{NO}_{3}{ }^{-}$values between $+0.07 \%$ and $+1.77 \%$. It is clear that the isotopic values of the group $\mathrm{B}$ mainly fall into the range for $\mathrm{NH}_{4}{ }^{+}$fertilizer and soil $\mathrm{N}$ sources (Figure 4). However, soil N cannot be considered as the significant nitrate source of the samples clustered into Group $\mathrm{B}$ because the concentrations of $\mathrm{NO}_{3}{ }^{-}$for group $\mathrm{B}$ ranging from 67.07 to $660.88 \mathrm{mg} / \mathrm{l}$ with an average $321.96 \mathrm{mg} / \mathrm{l}$ exceeded the $\mathrm{NO}_{3}{ }^{-}$concentrations produced by the mineralization of soil N (Puig et al. 2013). Groundwater samples of group $\mathrm{B}$ were collected from the agricultural areas which are far from the residential areas compared to Group A (Figure 2). $\mathrm{NH}_{4}{ }^{+}$fertilizers are very commonly used in these areas,

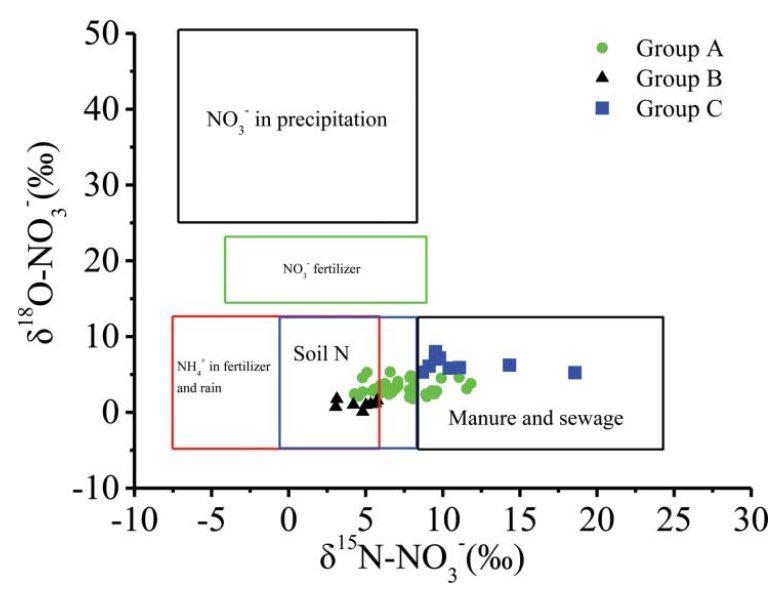

Figure 4. Identification of nitrate sources in the groundwater samples. 
revealing that the dominant nitrate source of these groundwater samples might be $\mathrm{NH}_{4}^{+}$fertilizers that underwent processes such as volatilization and nitrification (Yuan et al. 2012; Matiatos 2016).

Nitrate concentrations of Group $\mathrm{C}$ that included nine groundwater samples ranged from 9.35 to $203.40 \mathrm{mg} / \mathrm{l}$ with an average of $139.58 \mathrm{mg} / \mathrm{l} . \delta^{15} \mathrm{~N}^{-\mathrm{NO}_{3}}{ }^{-}$and $\delta^{18} \mathrm{O}-\mathrm{NO}_{3}{ }^{-}$values of Group $\mathrm{C}$ varied between $+8.68 \%$ and $+18.57 \%$ and $+5.23 \%$ and $+8.01 \%$. The isotopic signatures of group $\mathrm{C}$ mainly fell into the range for M\&S sources (Figure 4), suggesting that nitrate in groundwater samples mainly derived from M\&S. The sampling sites are located near the industrial and urban zones. A great deal of domestic sewage was directly discharged into the nearby ground or ditches without treatment due to the lack of wastewater treatment facilities in this study area. Therefore, nitrate in groundwater of group $\mathrm{C}$ might be attributed to leakage or disposal of untreated wastes from septic systems and industries. Moreover, a manure origin cannot be precluded because animal breeding frequently occurs at a small distance from the industrial and urban zones in this area. Since aquaculture is an important industry in coastal regions, coastal aquaculture might be an important nitrate source of the groundwater in group $\mathrm{C}$ near the aquaculture area due to the discharge of aquaculture wastewater.

Nitrogen transformations such as nitrification and denitrification are generally biogeochemical processes that may especially occur in shallow aquifers (Rivett et al. 2008; Xue et al. 2009; Hosono et al. 2013). Theoretically, $\mathrm{NO}_{3}{ }^{-}$derived from nitrification has $\delta^{18} \mathrm{O}$ $\mathrm{NO}_{3}{ }^{-}$values ranging from $-10 \%$ to $+10 \%$ (Xue et al. 2009). The measured $\delta^{18} \mathrm{O}-\mathrm{NO}_{3}{ }^{-}$values of the groundwater samples varied between $+0.07 \%$ and $+8.01 \%$ with a mean value of $+3.43 \%$ (Figure 5 ). These relatively low values suggested that nitrification was the dominant process in the groundwater. Typically, it is considered that $\mathrm{NO}_{3}{ }^{-}$produced from autotrophic nitrification contains two-thirds of the $\mathrm{O}_{2}$ from local water (e.g. soil water, groundwater, etc.) and one-third of the $\mathrm{O}_{2}$ from atmospheric oxygen (+23.5\%) (Wassenaar 1995). Therefore, measured $\delta^{18} \mathrm{O}-\mathrm{H}_{2} \mathrm{O}$ values in the groundwater can be used to estimate the theoretically $\delta^{18} \mathrm{O}-\mathrm{NO}_{3}{ }^{-}$of groundwater during nitrification. Measured $\delta^{18} \mathrm{O}-\mathrm{H}_{2} \mathrm{O}$ values of groundwater in the study area ranged from $-8.35 \%$ to $-4.63 \%$ with a mean value of
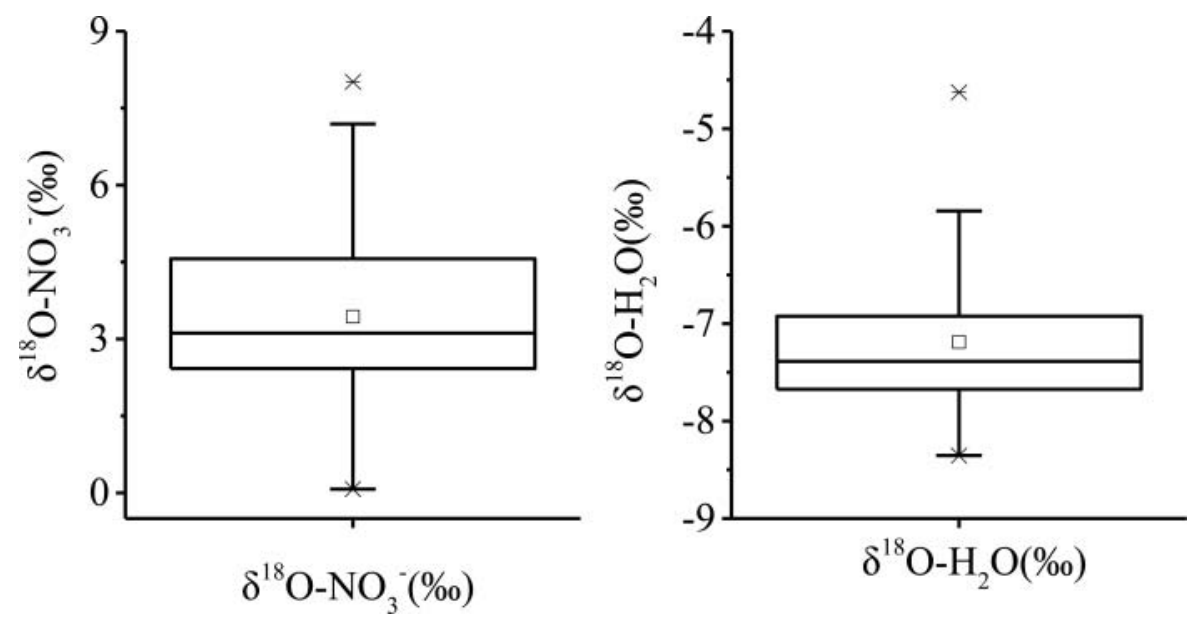

Figure 5. Box plots of $\delta^{18} \mathrm{O}-\mathrm{NO}_{3}{ }^{-}$and $\delta^{18} \mathrm{O}-\mathrm{H}_{2} \mathrm{O}$. 


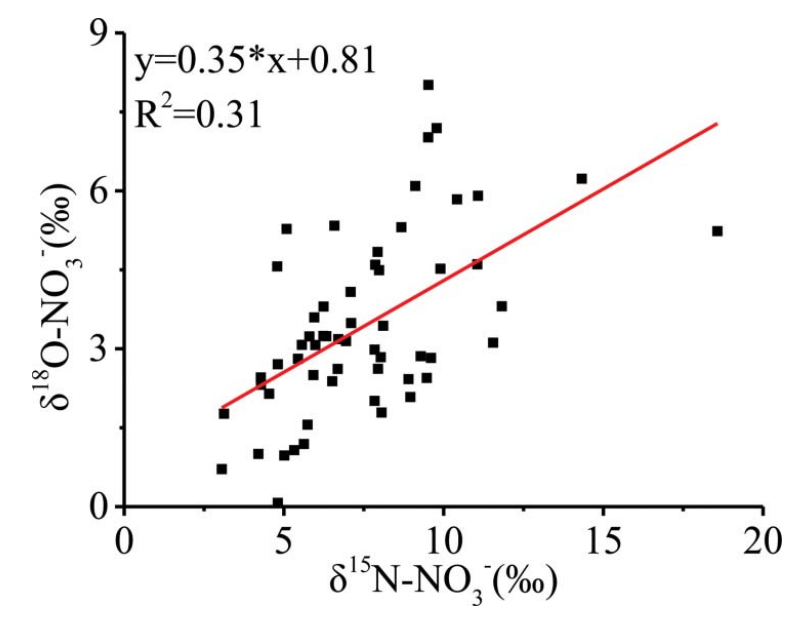

Figure 6. Relationship between $\delta^{15} \mathrm{~N}^{-\mathrm{NO}_{3}}{ }^{-}$and $\delta^{18} \mathrm{O}_{-} \mathrm{NO}_{3}{ }^{-}$values of the groundwater samples.

$-7.19 \%$ (Figure 5). Consequently, the expected $\delta^{18} \mathrm{O}-\mathrm{NO}_{3}{ }^{-}$values for groundwater nitrate derived from nitrification should be ranged from $+2.26 \%$ o to $+4.75 \%$ with mean value of $+3.04 \%$ according to the equation of $\delta^{18} \mathrm{O}-\mathrm{NO}_{3}{ }^{-}=2 / 3\left(\delta^{18} \mathrm{O}-\mathrm{H}_{2} \mathrm{O}\right)+1 / 3\left(\delta^{18} \mathrm{O}-\mathrm{O}_{2}\right)$ (Jakóbczyk-Karpierz et al. 2017). The theoretically expected value was close to but narrower than the measured $\delta^{18} \mathrm{O}-\mathrm{NO}_{3}{ }^{-}$values $\left(\delta^{18} \mathrm{O}-\mathrm{NO}_{3}{ }^{-}=+3.43 \% \mathrm{o} \pm+1.71 \% 0\right)$, indicating that groundwater nitrate was derived from the nitrification of organic soil $\mathrm{N}, \mathrm{NH}_{4}{ }^{+}$fertilizer, and $M \& S$.

In theory, a remarkably positive linear relationship between $\delta^{15} \mathrm{~N}-\mathrm{NO}_{3}{ }^{-}$and $\delta^{18} \mathrm{O}-\mathrm{NO}_{3}{ }^{-}$ will be observed if significant denitrification occurs (Singleton et al. 2007; Sacchi et al. 2013). No significant correlation of $\delta^{15} \mathrm{~N}_{-} \mathrm{NO}_{3}{ }^{-}$and $\delta^{18} \mathrm{O}-\mathrm{NO}_{3}{ }^{-}$was observed in the groundwater samples (Figures 4 and 6). Moreover, the DO concentrations in the groundwater samples illustrated in Table 1 were much higher than the $\mathrm{O}_{2}$ concentration suitable for denitrification (Rivett et al. 2008). In consideration of the oxic groundwater conditions, denitrification was not a major process in groundwater.

\section{Contribution of different nitrate sources determined by SIAR}

Based on the previous analysis of $\delta^{15} \mathrm{~N}-\mathrm{NO}_{3}{ }^{-}$and $\delta^{18} \mathrm{O}-\mathrm{NO}_{3}{ }^{-}$isotopic characteristic values for the groundwater samples, it is clear that nitrate in the groundwater originated from soil $\mathrm{N}, \mathrm{NH}_{4}{ }^{+}$fertilizer, and M\&S. However, the contribution rate of the potential nitrate sources cannot be distinguished by the bi-plot approach. To quantify the contribution proportions of the each nitrate source, SIAR model that can only be applied with two or more values (El Gaouzi et al. 2013) was used to estimate the probability distribution for the relative contribution of each source in the study area. Contribution proportions of different nitrate sources including soil $\mathrm{N}, \mathrm{NH}_{4}{ }^{+}$fertilizer, and M\&S for groundwater samples were determined by SIAR for Groups A, B, and C, respectively (Figure 7). The source contributions to groundwater nitrate were assessed by SIAR which incorporate the source uncertainty as the 25 th and 75 th confidence intervals, and the ranges of the mean values (Figure 7).

In this study, the mean values of contribution proportions were used for further analysis. The mean values revealed a high variability in contribution of the three potential $\mathrm{NO}_{3}{ }^{-}$ 

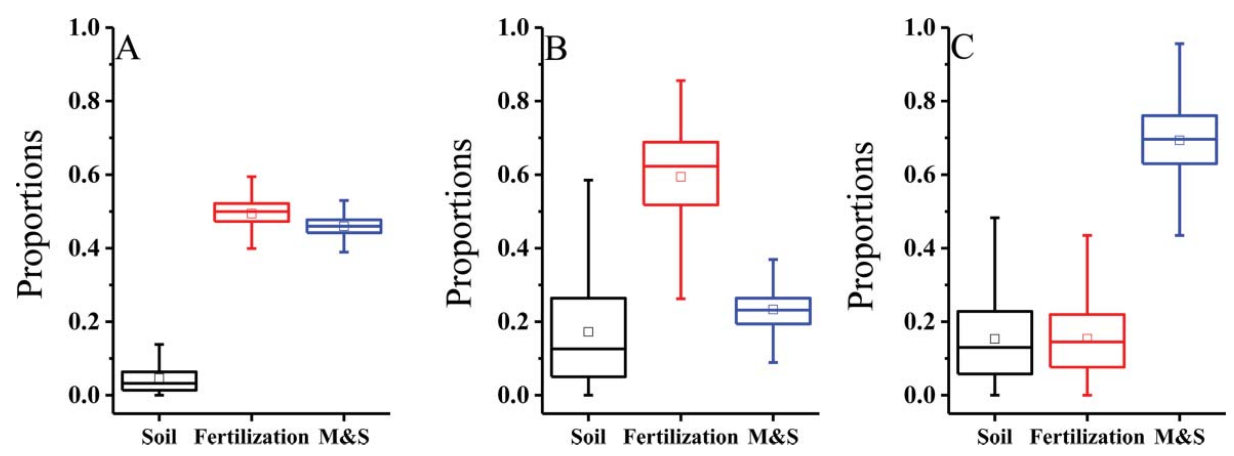

Figure 7. Contribution proportions of different nitrate sources for groundwater.

sources for different groups of the groundwater samples (Figure 7). The results demonstrated that $\mathrm{NH}_{4}{ }^{+}$fertilizer was the dominant source for groundwater samples of Group A, with the mean contribution proportion of $50 \%$. M\&S also contributed significantly, with the mean proportion of $46 \%$. The mean contribution proportion of soil $\mathrm{N}$ was only $4 \%$ for groundwater samples of Group A. $\mathrm{NH}_{4}{ }^{+}$fertilizer contributed $60 \%$ of the $\mathrm{NO}_{3}{ }^{-}$in groundwater for Group B. M\&S and soil N contributed to groundwater nitrate for Group B with average proportions of $23 \%$ and $17 \%$, respectively. M\&S served as dominant nitrate contribution source for the groundwater samples of group $\mathrm{C}$, with the mean contribution proportion of $70 \% . \mathrm{NH}_{4}{ }^{+}$fertilizer and soil $\mathrm{N}$ showed similar contribution pattern, contributing to the groundwater nitrate with proportions of $15 \%$ and $15 \%$, respectively.

On the whole, the nitrate source contributions determined by SIAR model were reasonable and in accordance with previous analysis by $\delta^{15} \mathrm{~N}-\mathrm{NO}_{3}{ }^{-}$and $\delta^{18} \mathrm{O}_{-} \mathrm{NO}_{3}{ }^{-}$isotope characteristics. Comparing the above findings with the specific $\mathrm{NO}_{3}{ }^{-}$pollution sources, it was found that the dominant nitrate pollution sources of groundwater $\mathrm{NO}_{3}{ }^{-}$ in the study area were $\mathrm{NH}_{4}{ }^{+}$fertilizer and M\&S. This may be attributed to two reasons. Firstly, chemical fertilizer and manure are widely used to increase crop production in the study area where winter wheat, summer maize, and vegetable crops are widely cultivated. Excessive use of fertilizer in China is well known, with average farmland application amount per unit area of three times the world average (Ministry of Environmental Protection 2011). In the study area, fertilizers (300-600 kg/ha) are usually applied for better cultivation. Moreover, organic fertilizers such as pig and cattle manures (500-1000 kg/ha) are also generally used for crops. However, the efficiency of utilizing fertilizers in China is only $30 \%-40 \%$, accompanying about half of the nitrogen lost by volatilization and another $5 \%-10 \%$ lost by leaching ( $\mathrm{Gu}$ et al. 2013). Excessive use of agricultural fertilizers in the area has deteriorated groundwater nitrate pollution. Secondly, sewage waste and/or manure are important nitrate sources in the groundwater of the study area. Industrial and domestic sources produce more than $3.0 \times 10^{10}$ $\mathrm{m}^{3}$ untreated sewage in China every year, and the sewage discharge into rivers is used for irrigation of farmland (Zhang et al. 2014). It is assumed that the amount of sewage will dramatically increase in the study area in accordance with significant progression of economic developments and urbanization. Moreover, this sewage is usually under low-level or no treatment before discharge, resulting in the high nitrate concentration in the groundwater. In addition, mineralization of soil organic $\mathrm{N}$ was another nitrate 
source of the groundwater. Due to the sea-water intrusion, soil salinization is serious in this region (Wen et al. 2012). In order to increase the soil organic matter content and control saline-alkali soil, straw and stalks of crops are widely reused in the study area (Jia et al. 2010) to cause increased soil organic N content. Soil organic N is an important source of $\mathrm{NO}_{3}{ }^{-}$pollution of groundwater, which is also corresponded by the findings of this study.

The results from SIAR outputs showed that $\mathrm{NO}_{3}{ }^{-}$in the groundwater mainly originated from $\mathrm{NH}_{4}{ }^{+}$fertilizer and M\&S. Although our results provide important information for controlling nitrate concentrations in the groundwater, it has some limitations. Firstly, only the spatial variation of nitrate sources in different groups was investigated in this study. Therefore, further research is necessary to understand the temporal variation of $\mathrm{NO}_{3}{ }^{-}$sources in the groundwater. Secondly, the mean and standard deviations of potential $\mathrm{NO}_{3}{ }^{-}$sources used in this study were mostly cited from literatures. Thus, the outputs obtained from SIAR model will become more precise if site-specific and more accurate isotope information on $\delta^{15} \mathrm{~N}_{-} \mathrm{NO}_{3}{ }^{-}$and $\delta^{18} \mathrm{O}-\mathrm{NO}_{3}{ }^{-}$values of sources from the study area can be obtained. Thirdly, the model gave large confidence intervals in this work, which might cause large uncertainty in the apportionment results. The outputs of Group A which had 40 samples showed smaller confidence intervals based on SIAR results, which illustrated that information derived from large number of samples could reduce the uncertainty and improve discrimination of nitrate source.

\section{Conclusions}

Stable isotope technique and SIAR model was firstly used to identify the nitrate sources and contribution proportions of different sources in typical coastal groundwater in northern China. About $91.5 \%$ of the groundwater samples collected from Laizhou Bay coastal area illustrated significantly high nitrate concentrations which exceeded WHO drinking water standard, reflecting the high risk of groundwater nitrate pollution in the study area. A total of 57 sampling sites were classified into three clusters according to HCA. The $\delta^{15} \mathrm{~N}-\mathrm{NO}_{3}{ }^{-}$ and $\delta^{18} \mathrm{O}-\mathrm{NO}_{3}{ }^{-}$values of groundwater samples from Group $\mathrm{C}$ were much higher than those from Groups A and B. SIAR results showed that $\mathrm{NH}_{4}{ }^{+}$fertilizer was the dominant nitrate source for groundwater samples of Groups A and B while manure and sewage served as dominant source for Group C. The results obtained in this study will provide important information for groundwater management and nitrate pollution control in the coastal zone.

\section{Acknowledgments}

The authors would like to thank the reviewers for their valuable suggestions on the manuscript.

\section{Funding}

This work was supported by One Hundred-Talent Plan of Chinese Academy of Sciences (Grant numbers of Y629041021 and Y610061033), National Natural Science Foundation of China (No. 41671319), Two-Hundred Talents Plan of Yantai (Y739011021), and Research Program of CAS Key Laboratory of Coastal Environmental Processes and Ecological Remediation (No. 1189010002). 


\section{References}

Bateman AS, and Kelly SD. 2007. Fertilizer nitrogen isotope signatures. Isotopes Environ Health Stud 43:237-47. doi:10.1080/10256010701550732

Chae GT, Yun ST, Mayer B, et al. 2009. Hydrochemical and stable isotopic assessment of nitrate contamination in an alluvial aquifer underneath a riverside agricultural field. Agric Water Manag 96:1819-27. doi:10.1016/j.agwat.2009.08.001

De Filippis G, Foglia L, Giudici M, et al. 2016. Seawater intrusion in karstic, coastal aquifers: Current challenges and future scenarios in the Taranto area (southern Italy). Sci Total Environ 573:134051. doi:10.1016/j.scitotenv.2016.07.005

ECETOC. 1988. Nitrate and drinking water, ECETOC Technical Report No. 27. European Chemical Industry, Ecology and Toxicology Centre, Brussels, Belgium

El Gaouzi FZJ, Sebilo M, Ribstein P, et al. 2013. Using $\delta^{15} \mathrm{~N}$ and $\delta^{18} \mathrm{O}$ values to identify sources of nitrate in karstic springs in the Paris basin (France). Appl Geochem 35:230-43. doi:10.1016/j. apgeochem.2013.04.015

Finlay JC, Sterner RW, and Kumar S. 2007. Isotopic evidence for in-lake production of accumulating nitrate in Lake Superior. Ecol Appl 17:2323-32. doi:10.1890/07-0245.1

$\mathrm{Fu} \mathrm{MZ}$, Xu XSH, Cheng ZHB, et al. 1994. The seasonal desertification-climate environment in the coastal areas of the yellow sea and Bohai Sea. J Desert Res 14(1):31-40 (in Chinese)

Gu B, Ge Y, Chang SX, et al. 2013. Nitrate in groundwater of China: Sources and driving forces. Glob Environ Change 23(5):1112-21. doi:10.1016/j.gloenvcha.2013.05.004

Grimmeisen F, Lehmann MF, Liesch T, et al. 2017. Isotopic constraints on water source mixing, network leakage and contamination in an urban groundwater system. Sci Total Environ 583:202-13. doi:10.1016/j.scitotenv.2017.01.054

Hales HC, Ross DS, and Lini A. 2007. Isotopic signature of nitrate in two contrasting watersheds of Brush Brook, Vermont, USA. Biogeochemistry 84:51-66. doi:10.1007/s10533-007-9074-6

Hosono T, Tokunaga T, Kagabu M, et al. 2013. The use of $\operatorname{delta}^{15} \mathrm{~N}$ and $\operatorname{delta}{ }^{18} \mathrm{O}$ tracers with an understanding of groundwater flow dynamics for evaluating the origins and attenuation mechanisms of nitrate pollution. Water Res 47:2661-75. doi:10.1016/j.watres.2013.02.020

$\mathrm{Hu}$ RL, Yue ZQ, Wang LC, et al. 2004. Review on current status and challenging issues of land subsidence in China. Eng Geol 76:65-77. doi:10.1016/j.enggeo.2004.06.006

Jackson AL, Inger R, Bearhop S, et al. 2009. Erroneous behaviour of MixSIR, a recently published Bayesian isotope mixing model: a discussion of Moore \& Semmens (2008). Ecol Lett 12:E1-E5. doi:10.1111/j.1461-0248.2008.01233.x

Jakóbczyk-Karpierz S, Sitek S, Jakobsen R, et al. 2017. Geochemical and isotopic study to determine sources and processes affecting nitrate and sulphate in groundwater influenced by intensive human activity - carbonate aquifer Gliwice (southern Poland). Appl Geochem 76:168-81. doi:10.1016/j. apgeochem.2016.12.005

Jia L, Wang W, Li Y, et al. 2010. Heavy metals in soil and crops of an intensively farmed area: a case study in Yucheng City, Shandong Province, China. Int J Environ Res Public Health 7:395-412. doi:10.3390/ijerph7020395

Kaown D, Koh DC, Mayer B, et al. 2009. Identification of nitrate and sulfate sources in groundwater using dual stable isotope approaches for an agricultural area with different land use (Chuncheon, mid-eastern Korea). Agric Ecosyst Environ 132:223-31. doi:10.1016/j.agee.2009.04.004

Kendall C. 1998. Tracing sources and cycling of nitrate in catchments. In: Kendall, C., McDonnell, J.J. (eds), Isotope Tracers in Catchment Hydrology. pp 519-576. Elsevier, Amsterdam

Kendall C, Elliott EM, and Wankel SD. 2007. Tracing anthropogenic inputs of nitrogen to ecosystems. In R.H. Michener and K. Lajtha (eds), Stable isotopes in ecology and environmental studies, 2nd ed, pp 375-449. Wiley-Blackwell Publishing, Oxford, UK

Lee KS, Bong YS, Lee D, et al. 2008. Tracing the sources of nitrate in the Han River watersheds in Korea, using $\delta^{15} \mathrm{~N}_{-\mathrm{NO}_{3}}$ and $\delta^{18} \mathrm{O}-\mathrm{NO}_{3}$ values. Sci Total Environ 395:117-24. doi:10.1016/j. scitotenv.2008.01.058

Li FM. 2005. Monitoring and numerical simulation of salt water intrusion in the Eastern Coast of Laizhou Bay, China. Ph.D. Dissertation, Ocean University of China (in Chinese) 
Matiatos I. 2016. Nitrate source identification in groundwater of multiple land-use areas by combining isotopes and multivariate statistical analysis: A case study of Asopos basin (Central Greece). Sci Total Environ 541:802-14. doi:10.1016/j.scitotenv.2015.09.134

Menció A, Mas-Pla J, Otero N, et al. 2016. Nitrate pollution of groundwater; all right..., but nothing else? Sci Total Environ 539:241-51. doi:10.1016/j.scitotenv.2015.08.151

Miller MP, Tesoriero AJ, Capel PD, et al. 2016. Quantifying watershed-scale groundwater loading and in-stream fate of nitrate using high-frequency water quality data. Water Resour Res 52:330-47. doi:10.1002/2015WR017753

Ministry of Environmental Protection of the People's Republic of China. 2011. National Groundwater Pollution Prevention and Control Plan. Released 28th November, (in Chinese)

Moore JW, and Semmens BX. 2008. Incorporating uncertainty and prior information into stable isotope mixing models. Ecol Lett 11: 470-80. doi:10.1111/j.1461-0248.2008.01163.x

Musgrove M, Opsahl SP, Mahler BJ, et al. 2016. Source, variability, and transformation of nitrate in a regional karst aquifer: Edwards aquifer, central Texas. Sci Total Environ 568:457-69. doi:10.1016/j. scitotenv.2016.05.201

Park SC, Yun ST, Chae GT, et al. 2005. Regional hydrochemical study on salinization of coastal aquifers, western coastal area of South Korea. J Hydrol (Amst) 313:182-94. doi:10.1016/j. jhydrol.2005.03.001

Parnell A, and Jackson A. 2008. SIAR: Stable isotope analysis in RAvailable from: http://cran.r-project. org/web/packages/siar/index.html

Parnell AC, Inger R, Bearhop , et al. 2010. Source partioning using stable isotopes: coping with too much variation. PLoS ONE 5 (3):e9672 doi:10.1371/journal.pone.0009672

Puig R, Folch A, Menció A, et al. 2013. Multi-isotopic study $\left({ }^{15} \mathrm{~N},{ }^{34} \mathrm{~S},{ }^{18} \mathrm{O},{ }^{13} \mathrm{C}\right)$ to identify processes affecting nitrate and sulfate in response to local and regional groundwater mixing in a large-scale flow system. Appl Geochem 32:129-41. doi:10.1016/j.apgeochem.2012.10.014

Re V, Sacchi E, Martin-Bordes JL, et al. 2013. Processes affecting groundwater quality in arid zones: The case of the Bou-Areg coastal aquifer (North Morocco). Appl Geochem 34:181-98. doi:10.1016/j.apgeochem.2013.03.011

Rivett MO, Buss SR, Morgan P, et al. 2008. Nitrate attenuation in groundwater: a review of biogeochemical controlling processes. Water Res 42:4215-32. doi:10.1016/j.watres.2008.07.020

Sacchi E, Acutis M, Bartoli M, et al. 2013. Origin and fate of nitrates in groundwater from the central Po plain: Insights from isotopic investigations. Appl Geochem 34:164-80. doi:10.1016/j. apgeochem.2013.03.008

Singleton MJ, Esser BK, Moran JE, et al. 2007. Saturated zone denitrification: potential for natural attenuation of nitrate contamination in shallow groundwater under dairy operations. Environ Sci Technol 41:759-65. doi:10.1021/es061253g

Urresti-Estala B, Vadillo-Pérez I, Jiménez-Gavilán P, et al. 2015. Application of stable isotopes $\left(\delta^{34} \mathrm{~S}\right.$ $\left.\mathrm{SO}_{4}, \delta^{18} \mathrm{O}-\mathrm{SO}_{4}, \delta^{15} \mathrm{~N}-\mathrm{NO}_{3}, \delta^{18} \mathrm{O}-\mathrm{NO}_{3}\right)$ to determine natural background and contamination sources in the Guadalhorce River Basin (southern Spain). Sci Total Environ 506-507:46-57. doi:10.1016/j.scitotenv.2014.10.090

Wassenaar LI. 1995. Evaluation of the origin and fate of nitrate in the Abbotsford Aquifer using the isotopes of $\delta^{15} \mathrm{~N}$ and $\delta^{18} \mathrm{O}$ in $\mathrm{NO}_{3}$. Appl Geochem 10:391-405. doi:10.1016/0883-2927(95)00013-A

Wen X, Diao M, Wang D, et al. 2012. Hydrochemical characteristicsand salinization processes of groundwater in the shallow aquifer of Eastern Laizhou Bay, China. Hydrol Process 26:2322-32. doi:10.1002/hyp. 8362

Xue D, Botte J, De Baets B, et al. 2009. Present limitations and future prospects of stable isotope methods for nitrate source identification in surface- and groundwater. Water Res 43(5):1159-70. doi:10.1016/j.watres.2008.12.048

Xue D, De Baets B, Van Cleemput O, et al. 2012. Use of a Bayesian isotope mixing model to estimate proportional contributions of multiple nitrate sources in surface water. Environ Pollut 161:43-9. doi:10.1016/j.envpol.2011.09.033

Yang L, Han J, Xue J, et al. 2013. Nitrate source apportionment in a subtropical watershed using Bayesian model. Sci Total Environ 463-464:340-7. doi:10.1016/j.scitotenv.2013.06.021 
Yin Z. 1992. Study on seawater intrusion in coastal area in Laizhou. Marine Publishing House, Beijing (in Chinese)

Yuan L, Pang Z, and Huang T. 2012. Integrated assessment on groundwater nitrate by unsaturated zone probing and aquifer sampling with environmental tracers. Environ Pollut 171:226-33. doi:10.1016/j.envpol.2012.07.027

Yue FJ, Li SL, and Hu J. 2015a. The Contribution of Nitrate Sources in Liao Rivers, China, Based on Isotopic Fractionation and Bayesian Mixing Model. Procedia Soc Behav Sci 13:16-20

Yue FJ, Li SL, Liu CQ, et al. 2015b. Sources and transport of nitrate constrained by the isotopic technique in a karst catchment: an example from Southwest China. Hydrol Process 29:1883-93. doi:10.1002/hyp.10302

Zhang Y, Li F, Zhang Q, et al. 2014. Tracing nitrate pollution sources and transformation in surfaceand ground-waters using environmental isotopes. Sci Total Environ 490:213-22. doi:10.1016/j. scitotenv.2014.05.004 